\title{
Sense Of Place Dan Social Anxiety Bagi Mahasiswa Baru Pendatang
}

\author{
Agus Jatmiko
}

Dosen Fakultas Tarbiyah dan Keguruan, IAIN Raden Intan Lampung

Diterima: 20 April 2016. Disetujui: 17 Juni 2016. Dipublikasikan: Nopember 2016

\begin{abstract}
Abstrak: Sense of place memiliki peranan dalam kecemasan sosial, dampak negatif yang bisa ditimbulkan dari kecemasan sosial salah satunya adalah menurunkan performansi akademik individu, sementara mahasiswa dituntut untuk dapat mencapai indeks prestasi tertentu (IP), jika kecemasan sosial yang dialami oleh mahasiswa baru meyebabkan performansi akademiknya turun, bukan tidak mungkin keadaan ini dapat membuat mahasiswa baru tidak dapat bertahan. Mahasiswa baru pendatang tidak dapat terlepas dari interaksi dengan lingkungan barunya, di mana interaksi ini akan terbentuk perasaan khusus terhadap lingkungannya atau sense of place. Bagaimana individu memaknai lingkungannya akan mempengaruhi psikologis individu tersebut.
\end{abstract}

Kata Kunci: Sense of place

\section{Pendahuluan}

Merantau merupakan bentuk migrasi yang dapat dilihat pada beberapa daerah di Indonesia. Fenomena 'merantau' didefinisikan oleh Kato sebagai 'meninggalkan kampung halaman untuk mencari kekayaan, ilmu pengetahuan, dan kemasyhuran'. Bentuk migrasi ini tidak permanen dan pada umumnya perantau-perantau masih ada hubungan yang kuat dengan kampong halamannya (Leake, 2009). Merantau bukan hanya terjadi dalam mencari pekerjaan namun juga pada mahasiswa yang akan melanjutkan pendidikan di perguruan tinggi. Tidak jarang mahasiswa memilih untuk melanjutkan pendidikan di perguruan tinggi di luar daerah asalnya.

Di tempat baru tersebut mahasiswa baru pendatang akan mengalami situasi yang berbeda dengan kehidupan ditempat asalnya misalnya saja perbedaan budaya, bahasa dan komunikasi, dari perbedaan keadaan tesebut mahasiswa baru pendatang harus dapat beradaptasi dengan lingkungan barunya. Selain itu, mahasiswa baru pendatang tersebut tidak dapat terlepas dari interaksi, dimana dalam interaksi ini akan terbentuk suatu perasaan khusus yang diterima oleh manusia yang dihasilkan dari suatu tempat dengan berbagai unsur didalamnya, termasuk orang-orang yang tinggal di dalamnya, perasaan khusus ini disebut sense of place (Arief, 2010). Menurut Rostamzadeh, Anantharaman dan Tong (2012) sense of place merupakan topik dari psikologi lingkungan yang didefinisikan sebagai hubungan emosional antara tempat dan manusia. Sense of place bukan hanya dijiwai dari setting fisik, tapi dari interpretasi manusia terhadap setting tersebut (Jorgensen dan Stedman, 2001).

Menurut Hashemnezhad (Nurhayati, 2015), sense of place adalah sebuah konsep menyeluruh dimana manusia dapat merasakan tempat, mempersepsikan diri mereka dan memiliki keterikatan pada tempat yang berarti bagi mereka. Sense of place diawali dengan sensasi yang mereka terima dari sebuah lingkungan, sensasi tersebut dapat berupa atmosfir dan kesan yang ditimbulkan kemudian dipersepsikan oleh individu, persepsi yang muncul dapat membuat sebuah makna subjektif terhadap tempat tersebut. Seperti yang dikatakan Arief (2010) dari interaksi akan terbentuk perasan khusus atau pemaknaan terhadap suatu tempat. Pemaknaan itu bisa berupa pemaknaan yang baik atau buruk. Pemaknaan yang buruk bagi mahasiswa baru pendatang dapat menjadi stressor, senada dengan yang dikatakan oleh Iskandar (2012), yaitu lingkungan yang berada disekitar manusia memberikan stimulasi yang dapat dimaknakan sebagai stressor atau stimulus yang dapat menimbulkan tekanan pada seseorang. Berdasarkan uraian tersebut dapat disimpulkan bahwa sense of place adalah bagaimana seseorang memaknai sebuah tempat, makna tersebut terbentuk dari stimulus yang 
dipersepsikan yang akhirnya baik atau buruk makna yang terbentuk akan mempengaruhi perilaku atau psikologis seseorang.

Iskandar (2012) menyatakan stimulus dari lingkungan akan dinilai oleh individu, dimana dalam penilaian ini akan memunculkan reaksi dan sebagai hasilnya jika individu dapat mengatasi stimulus yang datang dari lingkungan akan tercipta suatu kondisi, kondisi tersebut dapat berupa adaptasi (menoleransi lingkungan) atau adjustment (individu mengubah lingkungan agar sesuai dengannya). Sebaliknya, jika individu gagal dalam mengatasi stimulus yang datang akan terjadi stres, kecemasan, sakit dan lain sebagainya.

Hal senada juga dinyatakan oleh Setiowati, Wahyuningtyas dan Citra (2013), adanya perbedaan budaya dan belum saling mengenal satu sama lain akan menyebabkan seseorang secara psikologis mengalami kecemasan. Kecemasan adalah kondisi emosional yang tidak menyenangkan, yang ditandai oleh perasaan-perasaan subyektif seperti ketegangan, ketakutan dan kekhawatiran (Muarifah, 2005). Sebagai makhluk sosial individu tidak dapat terlepas dari interaksi, dimana dalam melakukan interaksi tidak semua individu merasa aman dan nyaman, namun ada juga yang memiliki perasaan cemas, takut, atau khawatir dengan lingkungan sekitarnya, kecemasan atau kekhawatiran yang berkaitan dengan situasi-situasi sosial ini disebut kecemasan sosial (Prawoto, 2010).

Menurut Suryabrata (Rahmawati, Yusainy, Nurwanti, 2014), kecemasan sosial merupakan suatu bentuk rasa cemas dan rasa takut yang diarahkan pada lingkungan sosialnya. Individu khawatir dirinya akan mendapat penilaian negatif dari orang lain. Individu juga khawatir tidak mampu mendapat persetujuan dari orang lain serta takut melakukan perilaku yang memalukan dimuka umum. Kecemasan sosial adalah ketakutan menetap dan tidak rasional yang umumnya berkaitan dengan keberadaan orang lain (Davision, Neale dan Kring, 2006). Individu dengan kecemasan sosial merasa khawatir terus-menerus diawasi dan dilihat negatif oleh orang lain dan menampilkan banyak sekali kecemasan terkait gejala dan perilaku sebelum, selama, dan setelah acara sosial, Clarke (Villiers, 2008).

Seseorang yang mengalami kecemasan sosial pada dasarnya tidak percaya diri untuk berinteraksi dengan orang lain, merasa bahwa mereka akan melakukan sesuatu untuk mempermalukan diri mereka sendiri, atau orang lain akan menghakimi mereka terlalu keras dan kritis (Gui dalam Prawoto, 2010). Penderita kecemasan sosial menilai dirinya lebih buruk daripada orang lain dan menurunkan kemampuan dan performansinya sehingga ia benar-benar lebih buruk Antony (Swasti dan Martani, 2013). Kecemasan sosial dalam kasus yang terjadi pada sebagian siswa dapat menghalangi mereka untuk menyelesaikan sasaran pendidikannya dan jika hal ini terus berlanjut dikhawatirkan akan menghalangi mereka untuk maju dalam karirnya (Marifah dan Budiani, 2012).

Hubungan antara manusia dengan lingkungan dapat dilihat dari teori yang dikemukakan oleh Lewin, dimana dikatakan bahwa perilaku merupakan fungsi dari manusia dan lingkungan. Individu berbeda dalam bagaimana mereka mengelola keberlangsungannya dengan lingkungan, hari perhari, jam perjam dan ada alasan untuk percaya bahwa perbedaanperbedaan ini memiliki banyak hubungan dengan kualitas keseluruhan penyesuaian mereka, termasuk kesehatan mereka atau penyakit moral, dan fungsi adaptif.

Penelitian mengenai sense of place yang dilakukan oleh Rostamzadeh, Anantharaman dan Tong (2012) yang dilakukan di Malaysia bertujuan untuk mengetahui pengaruh sense of place terhadap kesehatan mental atau penyesuaian psikologis, hasil dari penelitian ini ditemukan bahwa sense of place memberikan kontribusi yang signifikan terhadap kesehatan mental, temuan tersebut senada dengan yang ditemukan oleh Buchanan dan Fagg (Rostamzadeh et al, 2012), yaitu sense of place yang rendah memiliki peranan dalam masalah kesehatan mental, sebagai contoh, sense of place yang rendah menyebabkan kecemasan, gangguan suasana hati dan gangguan perilaku. 
Berdasarkan uraian diatas dapat dilihat bahwa sense of place memiliki peranan dalam kecemasan sosial, dampak negatif yang bisa ditimbulkan dari kecemasan sosial salah satunya adalah menurunkan performansi akademik individu, sementara mahasiswa dituntut untuk dapat mencapai indeks prestasi tertentu (IP), jika kecemasan sosial yang dialami oleh mahasiswa baru meyebabkan performansi akademiknya turun, bukan tidak mungkin keadaan ini dapat membuat mahasiswa baru tidak dapat bertahan.

\section{Hasil dan Pembahasan \\ Pengertian Sense of Place}

Sebelum membahas mengenai sense of place lebih jauh kita perlu memahami ruang (space) dan tempat (place) terlebih dahulu karena kaitannya sangat erat. Helpeny (Nurhayati, 2015) mendefinisikan tempat (place) sebagai sebuah lokasi spasial yang diberikan arti dan nilai oleh masyarakat atau individu. Manusia hidup di dalam sebuah ruang, dan manusia tinggal di dalam sebuah tempat. Lingkup ruang jauh lebih luas dibandingkan lingkup tempat (Arief, 2010).

Arief (2010) menganalogikan manusia primitif hidup di alam terbuka, namun mereka tetap membutuhkan perlindungan dari alam itu sendiri seperti dari ancaman bintang buas maupun cuaca, karenanya mereka tinggal dalam sebuah gua. Alam terbuka merupakan sebuah ruang (space) dan gua didefinisikan sebagai tempat (place). Ruang menjadi tempat ketika digunakan dan ditinggali, pengalaman adalah jantung dari arti tempat (Cresswell, 2009).

Sense of place merupakan topik dari psikologi lingkungan yang didefinisikan sebagai hubungan emosional antara tempat dan manusia. Tempat adalah posisi tertentu dengan komponen yang terbentuk didalamnya seperti atribut fisik atau karakteristik lokasi, makna atau persepsi dan aspek psikologi serta aktivitas yang mana komponen-komponen tersebut memainkan peran dalam membentuk sense of place. Dengan kata lain sense of place adalah konsekuensi dari hubungan timbal balik antara manusia dan tempat tinggalnya (Rostamzadeh et al, 2012).

Menurut Williams dan Kitchen (2012) sense of place merupakan persepsi individu mengenai lingkungan mereka sendiri yang meliputi struktur fitur sosial. Senada dengan itu, Jorgenson dan Stedman (2001) mendefinisikan sense of place sebagai makna yang melekat pada sebuah setting ruang bagi seseorang atau kelompok, sense of place tidak diilhami oleh keadaan fisik suatu tempat sendiri melainkan berada didalam interpretasi manusia terhadap keadaan itu. Sense of place mengacu pada keintiman berdasarkan pengalaman dengan proses alami, komunitas dan sejarah pada suatu tempat (Sanger, 1997).

Sense of place sering disebut sebagai susana tempat, kualitas lingkungan dan daya tarik dari tempat yang menyebabkan rasa sejahtera yang membantu mengikat masyarakat bersama dan membuat individu ingin kembali ke tempat tersebut, Williams, Patterson, Roggenbuck, dan Watson (Smith, 2011). Sense of place tidak terbatas pada warga asli tempat tersebut tetapi juga bagi pendatang dan wisatawan dapat tercipta keterikatan yang kuat terhadap tempat tersebut yang melambangkan pengalaman penting mereka (Smith, 2011).

Menurut Tuan (Arief, 2010) terdapat dua unsur penting dalam sense of place, yaitu pengalaman, dimana sebuah tempat akan dirasakan atau dialami oleh pengunjungnya, pengalaman memiliki konotasi yang pasif, kata ini menunjukan apa yang telah seseorang lalui dan terima, pengalaman itu sendiri disusun dari perasaan dan pemikiran. Unsur yang kedua, yaitu tempat itu sendiri, sebuah tempat menjadi ada ketika manusia mengetahui dan memberi makna pada sebagian ruang, pada keadaan tertentu, sebuah tempat dapat memiliki makna yang lebih kuat. Tempat ini yang biasa dikatakan memiliki sense of place yang kuat.

Berdasarkan uraian diatas dapat disimpulkan bahwa sense of place merupakan pemaknaan yang diberikan oleh individu terhadap sebuah tempat dengan berbagai unsur di dalamnya termasuk setting fisik tempat itu sendiri, pengalaman yang dialami oleh individu 
terhadap tempat tersebut dan interaksi yang terjalin dengan individu lain. Sense of place diawali dengan sensasi yang individu terima dari sebuah lingkungan, dari sensasi tersebut dapat terbentuk persepsi dimana persepsi yang muncul dapat membentuk sebuah makna subjektif terhadap tempat tersebut (Hashemnehad, 2013).

\section{Faktor yang Membentuk Sense of Place}

Seperti yang telah disebutkandiatas, sense of place merupakan persepsi subjektif individu mengenai lingkungan dan perasaan sadarnya terhadap tempat, hal ini menunjukan bahwa sense of place merupakan konsep psikologis dan fisik. Individu mengambil arti yang berbeda (positif atau negatif) dari tempat dan kemudian menyampaikan makna. Menurut Steele (Hashemnehad, 2013) faktor-faktor yang menciptakan sense of place, dibagi menjadi dua kategori: faktor kognitif dan persepsi; karakteristik fisik.

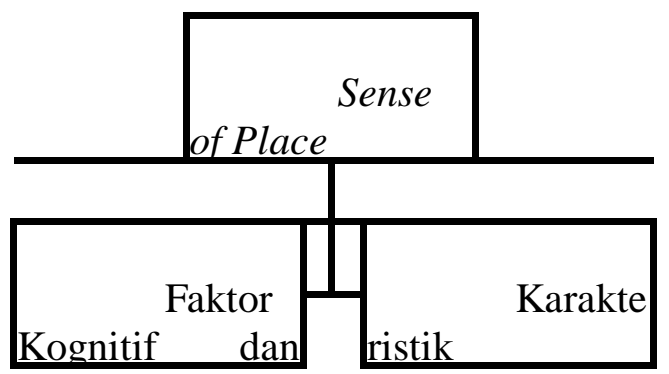

Gambar 1. Faktor Sense of Place, Steele

(Hashemnezhad, 2013)

\section{Faktor Kognitif}

Faktor kognitif meliputi makna yang dipersepsikan orang dari tempat. Jadi kita tidak bisa menyebut sense of place hanya sebuah perasaan emosional tentang satu tempat. Struktur kognitif adalah dimana individu dapat memberikan hubungan dalam memaknainya. Akibatnya, atara individu akan berbeda dalam memaknai tempat tergantung pada pengalaman mereka, motivasi mereka, latar belakang intelektual mereka, dan karakteristik fisik lingkungan (Hashemnezhad, 2013).

\section{Faktor Fisik}

Steele (Hashemnezhad, 2013) menjelaskan bahwa karakterisktik lingkungan fisik tidak hanya untuk membedakan antara tempat yang satu dengan tempat yang lain tetapi juga berpengaruh pada makna yang orang dipersepsikan tentang tempat terssebut. Steele menjelaskan parameter fisik yang berpengruh pada sense of place seperti : luas tempat, komponen, keanekaragaman, tekstur, dekorasi, warna, bau, kebisingan, temperatur dan lainlain. Steele juga menjelaskan bahwa identitas, sejarah, hiburan, hal- hal yang menyenangkan, keindahan, vitalitas dan memori juga memiliki efek pada cara individu berkomunikasi dengan tempat.

\section{Dimensi Sense of Place}

Long (Hashemnezhad, 2013) menyatakan secara umum interaksi antara manusia dengan tempat atau place terdiri dari tiga dimensi, yaitu kognitif, perilaku dan emosi. Aspek kognitif dari interaksi yang menyebabkan persepsi spasial, dan pada saat itu individu mengetahui unsur-unsur lingkungan dan menggunakannya sebagai menavigasi untuk jalan mereka. Aspek perilaku dari interaksi adalah untuk aktivitas dan hubungan fungsional antara manusia dengan lingkungan. Aspek emosional dimana persepsi dari kepuasan dan kelekatan terhaap tempat.

Menurut Iskandar (2001), pemaknaan atau penilaian mengenai lingkungan melibatkan tiga komponen, yaitu kognisi, afeksi dan konasi. Hal senada juga dikemukakan oleh Center 
(Jorgensen dan Stedman, 2001) yang menjelaskan proses yang melibatkan integrasi domain yang memungkinkan membentuk teori yang kuat dari hasil hubungan antara beberapa aspek psikologis dimana tiga aspek ini diperoleh dari konstruk yang dapat membentuk suatu tempat, tiga aspek psikologis ini, yaitu proses kognitif, afeksi dan konasi. Ketiga aspek ini memiliki kesamaan dengan literatur yang terdapat dalam psikologi lingkungan, yaitu place identity, place dependence, dan place attachment.

\section{Place Identity}

Konsep identitas tempat (place identity) pada dasarnya mengulas hubungan antara "siapa kita" dan "dimana kita", dan "bagaimana lingkungan lokal kita" (termasuk lokasi geografis, tradisi, budaya, warisan budaya, dan sebagainya) mempengaruhi hidup kita, Fisher (Ernawati, 2014). Place identity melibatkan dimensi diri yang menegaskan identitas pribadi individu dalam hubungannya dengan lingkungan fisik yang memiliki pola yang kompleks dari kesaradan dan ketidaksadaran, ide, keyakinan, kesukaan, perasaan, nilai-nilai, tujuan, kecenderungan perilaku dan kemampuan yang relevan dengan lingkungan (Jorgensen dan Stedman, 2001).

Smith (2011), menyatakan terdapat tiga aspek dalam membentuk place identity, yaitu: (1) Perspektif kognitif, mengacu kepada 'whereness' dan 'whatness' (arti), yang melibatkan kognitif individu dalam menyandikan lingkungan spasial dan evaluasi lingkungan, (2) Teori konsep diri, dijelaskan bahwa diri adalah hasil dari proses perbedaan sosial yang diperantarai oleh pengalaman sosial, akibatnya individu mampu membedakan antara dirinya sendiri, orang lain dan lingkungan fisik yang merupakan hasil dari pengembangan diri mereka. Teori ini berfokus pada aspek kognitif sehingga identitas tempat terkonseptual didalam kognisi, (3) Pengaruh sosiologis dan cara pandang fenomenologis. Pengaruh sosiologis artinya tempat dapat menjadi penting untuk berbagi makna atau identitas budaya, dengan demikian identitas tempat mungkin didasarkan pada ikatan emosional pribadi, seperti taman favorit ketika kecil, atau didasarkan pada makna yang lebih abstrak dan simbolik, seperti bagaimana taman nasional sebagai simbol dari warisan masyarakat. Cara pandang fenomenologis, pendekatan ini menekankan ikatan emosional terhadap lingkungan dan berfokus pada pengalaman subjektif dari lingkungan.

\section{Place Dependence}

Place dependence adalahkekuatan asosiasi antara individu dengan tempat tertentu, seberapa baik individu dapat mencapai sebuah tujuan dengan beberapa alternatif pilihan yang terdapat pada suatu tempat, Stokols dan Shumaker (Jorgensen dan Stedman, 2001). Dua komponen dari place depencence adalah kualitas tempat dalam hal tersedianya sumber daya fisik dan sosial untuk memuaskan tujuan individu, dan bagaimana tempat tersebut dibandingkan dengan tempat lain. Dependence atau ketergantungan terhadap sebuah tempat terjadi ketika sumberdaya fisik dan sosial di lingkungan tempat tinggal sesuai dengan kebutuhan penting individu, Stokols dan Shumakers (Smith, 2011).

\section{Place Attachment}

Place attachmen didefinisikan sebagai ikatan positif yang terbangun antara individu atau kelompok dengan lingkungannya, Altman dan Low (Jorgensen dan Stedman, 2001). Place attachment sebagai hubungan afektif yang individu bangun dengan setting tempat dimana individu cenderung untuk tinggal atau berdiam dan dimana individu merasa aman dan nyaman, Hidalgo dan Hernandez (Kamalipour, Yeganeh dan Alalhesabi, 2011). Place attachment juga melibatkan perasaan aman yang terkait dengan lokasi georgrafis atau atribut tertentu, Jones (Smith, 2011). Pada dasarnya pengalaman positif adalah konsekuensi dari emosi dan keyakinan baik yang individu bangun dalam berinteraksi dengan tempat, dalam proses ini individu mengembangkan hubungan mereka dengan tempat dan individu lain. Ada hubungan langsung antara tingkat place attachment dan ketertarikan individu terhadap tempat, dimana semakin individu attach terhadap tempat, dia akan semakin peduli terhadap tempat tersebut, Mesch dan Monar (Hashemnezhad, 2013). 


\section{Pengertian Social Anxiety}

Merasa khawatir dan tidak nyaman saat harus memulai percakapan atau berinteraksi dengan orang lain, menjadi fokus perhatian atau berada dalam situasi-situasi yang mengundang unsur penilaian atau evaluasi dari orang lain mungkin banyak kita jumpai didalam kehidupan sehari-hari. Kecemasan seperti itu muncul mungkin karena takut tidak dapat menyesuaikan diri, diabaikan, ditertawakan, takut tidak direspon dengan baik, diremehkan, takut dinilai bodoh dan sebaginya, kecemasan atau kekhawatiran yang berkaitan dengan situasi-situasi sosial di atas disebut kecemasan sosial, Antony \& Swinson (Suryaningrum, 2005).

Menurut La Greca dan Lopez (Junttila, Laakkonen, Niemi dan Ranta, 2011) kecemasan sosial adalah pengalaman rasa takut, cemas atau khawatir tentang situasi sosial dan takut dievaluasi oleh orang lain. Hal ini bisa terjadi akibat pengalaman negatif, permusuhan atau pengalaman khusus dengan teman sebaya yang mungkin selanjutnya dapat menghambat interaksi sosial yang diperlukan untuk perkembangan sosioemosional. Menurut DeWall (Rahmawati et al, 2014), kecemasan sosial merupakan sebuah fenomena yang ditandai oleh rasa takut dan distres. Kecemasan sosialditandai dengan melihat interaksi sosial sebagai kompetitif, kewaspadaan yang berlebihan pada tanda-tanda ancaman sosial, dan menghindari interaksi yang dapat mengakibatkan penolakan sosial. Pada skala ekstrem kecemasaan sosial berkaitan dengan kondisi kesehatan mental, seperti masalah penyalahgunaan zat, depresi, keinginan bunuh diri, dan percobaan bunuh diri.

Davision et al (2006) mendefinisikan kecemasan sosial sebagai ketakutan menetap dan tidak rasional yang umumnya berkaitan dengan keberadaan orang lain. Individu dengan kecemasan sosial biasanya mencoba menghindari situasi dimana ia mungkin dinilai dan menunjukan tanda- tanda kecemasan atau berperilaku secara memalukan. Inti dari kecemasan sosial adalah takut malu dan penghinaan dalam situasi sosial (Kreifelts, Bruck, Ritter, Ethofer, Domin, Lotze, Jacob, Schlipf, dan Wildgruber, 2014).

Definisi lain mengenai kecemasan sosial menurut Swasti dan Martani (2013), yaitu ketakutan berlebihan menerima kritik dari orang lain, yang mengarahkan individu menghindari interaksi dengan sekelompok orang atau kelompok sosial. Kecemasan sosial diartikan sebagai kekhawatiran dan ketakutan yang dialami oleh individu dalam berinteraksi dengan orang lain, dalam situasi penilaian dan atau menjadi fokus perhatian orang lain, Butler (Suryaningrum, 2005). Kecemasan sosial ditandai oleh rasa takut yang muncul karena perasaan malu, dan evaluasi negatif oleh orang lain dalam situasi sosial sehingga cenderung untuk menghindari situasi sosial yang ditakutinya, Varcarolis (Rohmah, 2013). Hal tersebut menyebabkan individu dengan kecemasan sosial sering kali bekerja dalam pekerjaan atau profesi yang jauh di bawah kemampuan atau kecerdasan mereka karena sensitivitas sosial ekstrem yang mereka alami (Davision et al, 2006).

Kecemasan sosial meningkat menjadi gangguan bila; pertama, tingkat kecemasan yang dialami semakin irasional dan mengganggu efektivitas kegiatan sehari-hari, kedua, justifikasi terhadap kecemasan berlebihan, misalnya individu merasakan tingkat kecemasan tinggi tanpa stimulus pemicu, dan ketiga, konsekuensi dari kecemasan tersebut membawa dampak negatif menyeluruh dalam hidup individu, Sternberg (Swasti dan Martani, 2013).

Hal tersebut sesuai dengan yang terdapat pada DSM-IV (2000) dimana individu dikatakan memiliki gangguan kecemasan sosial jika memenuhi beberapa kriteria, yaitu (1) Ketakutan yang menetap pada satu atau lebih situasi sosial, ketika seseorang harus bertemu dengan orang baru atau tidak dikenal dan orang-orang tersebut akan mencermatinya, (2) Menghadapi ketakutan terhadap situasi sosial yang selalu memicu timbulnya kecemasan, (3) Individu tersebut mengakui jika ketakutannya berlebihan atau tidak masuk akal, (4) Situasi sosial yang ditakutkan itu dihindari jika tidak akan menimbulkan kecemasan yang menetap atau distres, (5) Adanya perilaku menghindar, (6) Adanya upaya antisipasi, (7) Kondisi distres ini secara signifikan berpengaruh terhadap rutinitas normal seperti sekolah, pekerjaan, atau 
hubungan dengan orang lain, atau dirinya mengalami distres yang menetap karena fobia yang dialaminya.

\section{Tipe Gangguan Kecemasan Sosial}

Gangguan kecemasan sosial dapat bersifat umum atau khusus, tergantung rentang situasi yang ditakuti dan dihindari. Individu dengan tipe umum mengalami gangguan kecemasan social ini pada usia yang lebih awal, lebih banyak komorbiditas dengan berbagai ganguan lain, seperti depresi dan kecanduan alkohol. Gangguan kecemasan sosial cenderung menjadi kronis jika penanganannya tidak berhasil (Davision et al, 2006). Kecemasan sosial sebagai pengalaman satu atau dua situasi sosial tertentu (spesifik atau bukan kecemasan umum) atau sebagian besar atau semua situasi sosial (kecemasan sosial umum). Salah satu contoh dari kecemasan sosial tertentu adalah seseorang yang hanya merasa takut ketika menulis didepan orang lain namu merasa nyaman ketika berbicara didepan orang lain, Hoffman (Villiers, 2009).

\section{Situasi yang dapat membangkitkan kecemasan social}

Holt, Heimberg, Harapan, dan Liebowitz (Leary dan Kowalsky, 1995) menyatakan situasi yang dapat memicu kecemasan sosial dapat diklasifikasikan ke dalam empat kategori utama. Pertama, yaitu situasi yang melibatkan interaksi dan berbicara formal, berbicara didepan audience, tampil di pangung, memberikan laporan kepada grup, berbicara di dalam rapat dan sejenisnya. Kategori kedua situasi yang menginduksi kecemasan sosial melibatkan interaksi dan pembicaraan informal. Kategori ini mencakup situasi seperti pergi kepesta dan bertemu dengan orang asing. Ketiga, situasi yang membutuhkan perilaku asertif (mengekspresikan ketidaksetujuan atau menolak penjual ketika ditawarkan barang dengan harga tinggi) juga memicu kecemasan sosial. Keempat, individu kadang merasa cemas secara sosial ketika mereka hanya diamati oleh orang lain saat bekerja, menulis, atau makan.

\section{Tabel 1. Situasi Domain Kecemasan Sosial Holt, Heimberg, Harapan, dan Liebowitz (Leary dan Kowalsky, 1995)}

\section{Situasi}

Interaksi dan berbicara formal

Interaksi dan berbicara informal

Interaksi asertif

\section{Contoh}

\section{Berpartisipasi dalam group, acting}

Menghadiri pesta, menyapa seseorang yang tidak dikenal dengan baik

Berbicara dengan sosok otoritas, mengekspresikan ketidaksetujuan pada seseorang

Perilaku yang diobservasi Makan dimana ada orang lain yang melihat

\section{Dampak Negatif Kecemasan Sosial}

Dampak negatif yang ditimbulkan dari kecemasan sosial dapat berupa penurunan fungsi peran sosial dan perkembangan karir, penurunan kesejahteraan subjektif dan kualitas hidup, Wittchen dan Fehm (Muarifah dan Budiani, 2012). Hal senada juga dikemukan oleh Castella, Goldin, Jazaieri, Ziv, Heimberg, dan Gross, (2014) individu dengan kecemasan sosial menunjukan sering menunjukan kesalahan ditempat kerja, sekolah, persahabatan dan hubungan intim. kecemasan sosial juga berhubungan dengan self-esteem yang rendah dan kualitas hidup yang buruk secara keseluruhan Davision et al (2004) menyatakan bahwa perilaku yang tidak tepat atau kurangnya keterampilan sosial sebagai penyebab kecemasan sosial. Individu tidak pernah belajar bagaimana berperilaku agar ia merasa nyaman dengan orang lain atau individu tersebut berulang kali melakukan kecerobohan, kikuk dan secara sosial tidak kompeten, serta sering dikritik oleh rekan-rekan sosial. Mereka tidak mampu memberikan respon pada waktu serta tempat yang tepat dalam interaksi sosial, misalnya mengucapkan "terima kasih" pada waktu yang tepat, Fischetti, Curran, dan Wessberg (Davision et al, 2004). 


\section{Aspek-Aspek Kecemasan Sosial}

La Greca dan Lopez (Junttila, Laakkonen, Niemi dan Ranta, 2011) mengemukakan ada tiga aspek kecemasan sosial yaitu :

a. Ketakutan akan evaluasi negatif.

Individu seakan memiliki banyak alasan yang baik untuk peduli dengan bagaimana orang lain memandang mereka, dan tidak masuk akal dimana kadang-kadang mereka menjadi khawatir tentang reaksi orang lain. Kecemasan sosial terjadi ketika individu merasa khawatir tentang bagaimana mereka dipandang dan dinilai oleh orang lain (Leary dan Kowalsk, 1995).

b. Penghindaran sosial dan rasa tertekan dalam situasi yang baru atau berhubungan dengan orang asing. Mencerminkan pengindaran sosial dan distress dengan situasi baru atau orang yang tidak familiar. Penghindaran sosial dan distress berarti ketidaknyamanan, kesulitan dan penghindaran atau hambatan yang dirasakan individu pada orang lain, kecemasan muncul ketika bertemu dengan orang-orang baru atau ketika individu melakukan sesuatu yang baru didepan orang lain, misalnya presentasi di depan kelas, La Greza dan Lopez (Junttila et al, 2011).

c. Penghindaran sosial dan rasa tertekan yang dialami secara umum atau dengan orang yang dikenal. Senada dengan penghindaran sosial dan distres yang dialami dalam situasi yang baru atau dengan orang asing, penghindaran sosial dan distress berarti ketidaknyamanan, kesulitan dan penghindaran atau hambatan yang dirasakan individu pada orang lain, namun pada aspek umum individu cenderung diam dan malu bahkan dengan kelompok yang familiar dan takut menerima undangan teman-temannya untuk bergabung atau melakuka hal-hal bersama dengan mereka, La Greza dan Lopez (Junttila et al, 2011).

Beberapa uraian di atas dapat dipahami bahwa Sense of place adalah konsekuensi dari hubungan timbal balik antara manusia dan tempat tinggalnya (Rostamzadeh et al, 2012). Manusia tidak dapat terlepas dari interaksi dengan lingkungannya, dalam interaksi ini akan terbentuk suatu perasaan khusus yang diterima oleh manusia yang dihasilkan dari suatu tempat dengan berbagai unsur di dalamnya, termasuk orang-orang yang tinggal di dalamnya, perasaan khusus ini disebut sense of place (Arief, 2010).

Tidak semua individu merasa aman dan nyaman dalam melakukan interaksi, namun ada juga yang memiliki perasaan cemas, takut, atau khawatir dengan lingkungan sekitarnya, kecemasan atau kekhawatiran yang berkaitan dengan situasi-situasi sosial ini disebut kecemasan sosial (Prawoto, 2010). Menurut DeWall (Rahmawati et al, 2014), kecemasan sosial merupakan sebuah fenomena yang ditandai oleh rasa takut dan stres. Kecemasan sosial ditandai dengan melihat interaksi sosial sebagai kompetitif, kewaspadaan yang berlebihan pada tandatanda ancaman sosial, dan menghindari interaksi yang dapat mengakibatkan penolakan sosial. Iskandar (2012) juga menyatakan stimulus dari lingkungan akan dinilai oleh individu, dimana dalam penilaian ini akan memunculkan reaksi dan sebagai hasilnya jika individu dapat mengatasi stimulus yang datang dari lingkungan akan tercipta suatu kondisi, kondisi tersebut dapat berupa adaptasi (menoleransi lingkungan) atau adjustment (individu mengubah lingkungan agar sesuai dengannya). Sebaliknya, jika individu gagal dalam mengatasi stimulus yang datang akan terjadi stres, kecemasan, sakit dan lain sebagainya.

\section{Simpulan}

Dari penjelasan di atas dapat ditarik kesimpulan bahwa bagaimana individu memaknai lingkungannya (sense of place) akan berdampak pada psikologisnya. Hal tersebut didukung oleh penelitian yang dilakukan Rostamzadeh et al (2012) bahwa sense of place memberikan kontribusi yang signifikan terhadap kesehatan mental, temuan tersebut senada dengan yang ditemukan oleh Buchanan dan Fagg (Rostamzadeh et al, 2012), yaitu sense of place yang rendah memiliki peranan dalam masalah kesehatan mental, sebagai contoh, sense of place yang rendah menyebabkan kecemasan, gangguan suasana hati dan gangguan perilaku. 
Mahasiswa baru pendatang tidak dapat terlepas dari interaksi dengan lingkungan barunya, dimana seperti yang telah dijelaskan sebelumnya dari interaksi ini akan terbentuk perasaan khusus terhadap lingkungannya atau sense of place. Bagaimana individu memaknai lingkungannya akan mempengaruhi psikologis individu tersebut. Hal tersebut dipertegas oleh Arief (2010) dari interaksi akan terbentuk suatu pemaknaan terhadap suatu tempat, dimana pemaknaan itu bisa berupa pemaknaan yang baik atau buruk. Pemaknaan yang buruk bagi mahasiswa baru pendatang dapat menjadi stressor. Prawoto (2010) menjelaskan bahwa dalam melakukan interaksi tidak semua individu merasa aman dan nyaman, namun ada juga yang memiliki perasaan cemas, takut, atau khawatir dengan lingkungan sekitarnya.

Kecemasan atau kekhawatiran yang berkaitan dengan situasi-situasi sosial ini disebut kecemasan sosial. Kecemasan sosial ditandai dengan melihat interaksi sosial sebagai kompetitif, kewaspadaan yang berlebihan pada tanda-tanda ancaman sosial, dan menghindari interaksi yang dapat mengakibatkan penolakan sosial. Kecemasan sosial dalam kasus yang terjadi pada sebagian mahasiswa dapat menghalangi mereka untuk menyelesaikan sasaran pendidikannya dan jika hal ini terus berlanjut dikhawatirkan akan menghalangi mereka untuk maju dalam karirnya (Marifah dan Budiani, 2012).

\section{Daftar Pustaka}

Arief, A. (2009). Penciptaan Sense of Place dalam Lingkup Ruang Virtual Studi Kasus : Grand Theft Auto San Andreas. Skripsi. Tidak diterbitkanFakultas Teknik Departemen Arsitektur Universitas Indonesia.

Castella, K., Goldin, P., Jazaieri, H., Ziv, M., Heimberg, R., dan Gross, J. (2014). Emotion beliefs in social anxiety disorder: Associations with stress, anxiety, and well-being. Australian Journal of Psychology. 66: 139-148. doi: 10.1111/ajpy.12053

Davision, G. C., Neale, J. M., \& Kring, A. M. (2012). Psikologi Abnormal. Jakarta: PT Raja Grafindo Persada.

Hashemnezhad, H., Yazdanfar, A., Heidari, A., Behdadfar, N. (2013). Comparison the concepts of sense of place and attachment to place in Architectural Studies. Malaysia Journal of Society and Space. 9 (1)

Iskandar, Z. (2012). Psikologi Lingkungan Teori dan Konsep. Bandung : PT. Refika Aditama

Jorgensen, B. Stedman, R. (2001). Sense of Place as an Attitude : Lakeshore Owners Attitudes Toward Their Properties. Journal of Environmental Psychology. 21, 233-248. doi:10.1006/jevp.2001.0226.

Juntilla, N., Laakonen, E., Niemi, dan Ranta, K. (2011). Modeling the Interrelations of Adolescent, Loneliness, Social Anxiety and Social Phobia. Center for Learning Research, University of Turku.

Kreifelts, B., Bruck, C., Ritter, J., Ethofer, T., Domin, M., Lotze, M., Jacob, H., Schlipf, S., dan Wildgruber, D. (2014). They Are Laughing at Me: Cerebral Mediation of Cognitive Biases in Social Anxiety. University of Leicester, United Kingdom. 9 (6). doi:10.1371/journal.pone.0099815

Leake, R. (2009). Pulau Putri: Kebudayaan Migrasi dan Dampaknya di Pulau Bawean. Fakultas Ilmu Sosial dan Ilmu Politik Universitas Muhammadiyah Malang. Skripsi

Leary, M., Kowalski, B. (1995). Social Anxiety. New York : Guilford Press.

Marifah, N., Budiani, M. (2012). Hubungan Antara Attachment Stye dan Self-Esteem dengan Kecemasan Sosial pada Remaja. Fakultas Psikologi Universitas Negeri Surabaya. 
Jurnal Online Universitas Negeri Surabaya. 3 (1). https://www.scribd.com/doc/189895778/Hubungan-Antara-Attachment-Style-DanSelf-Esteem-Dengan-Kecemasan-Sosial-Pada-Remaja. Diakses pada tanggal 29/03/2015 jam 16.25

Muarifah, A. (2005). Hubungan Kecemasan dan Agresivitas. Indonesian Psychological Journal. 2 (2).

Nurhayati, Y. (2015). Sense of Place pada Masyarakat yang Tinggal di Sekitar TPA Supit Urang Kota Malang. Skripsi. Tidak diterbitkan. Program Studi Psikologi Fakultas Ilmu Sosial dan Ilmu Politik Universitas Brawijaya.

Prawoto, Y. (2010). Hubungan Antara Konsep Diri Dengan Kecemasan Sosial pada Remaja Kelas XI SMA Kristen 2 Surakarta. Skripsi. Tidak diterbitkan. Program Studi Psikologi Fakultas Kedokteran Universitas Sebelas Maret Surakarta.

Rahmawati, S., Yusainy, C., Nurwanti, R. (2014). Selfie: Peranan Jenis Komentar Terhadap Hubungan Antara Kecemasan Sosial dan Perilaku Agresif Pelaku Selfie. Skripsi. Tidak diterbitkan. Program Studi Psikologi, Fakultas Ilmu Sosial dan Ilmu Politik, Universitas Brawijaya.

Rostamzadeh, M., Anantharaman, R., Tong, D. (2012). Sense of Place on Expatriate Mental Health in Malaysia. Iternational Journal of Social Science and Humanity. 2 (5). Doi: 10.7763/IJSSH.2012.V2.126

Setiowati, E., Wahyuningtyas, B., Citra, A. (2013). Manajemen Ketidakpastian dan Kecemasan Mahasiswa Asal Daerah yang Kuliah di Jakarta (Studi tentang Dinamika Interaksi Mahasiswa Universitas Bina Nusantara dan Universitas Indonesia Asal Daerah dengan Lingkungan Pergaulannya). Bina Nusantara Akademic Journals. http://marcomm.binus.ac.id/academic-journals/manajemen-ketidakpastian-dankecemasan-mahasiswa-asal-daerah-yang-kuliah-di-jakarta-studi-tentang-dinamikainteraksi-mahasiswa-universitas-bina-nusantara-dan-universitas-indonesia-asaldaerah-dengan/. Diakses pada tanggal 22 januari 2015, 21:13

Smith, K.(2011). The Relationship between Residential Satisfaction, Sense of Community, Sense of Belonging and Sense of Place in a Western Australian Urban Planned Community. Faculty of Computing, Health \& Science. Thesis. (http://ro.ecu.edu.au/cgi/viewcontent.cgi?article=1460\&context=theses). (online). Diakses pada tanggal 07 April 2015 jam 7.00 WIB

Suryaningrum, C. (2005). Terapi Kognitif-Tingkah Laku untuk Mengatasi Kecemasan Sosial. Tesis. Tidak diterbitkan. Fakultas Psikologi Universitas Indonesia.

Swasti, I., Martani, W. (2013). Menurunkan Kecemasan Sosial melalui Pemaknaan Kisah Hidup. Jurnal Psikologi Universitas Gadjah Mada. 40 (01)

Villiers, D. (2008). Perfectionism and Social Anxiety among College Students. Counseling Psychology Dissertations. Disertasi. 